\title{
Students' perceptions of self-assessment and their approaches to learning in university mathematics
}

\author{
Riikka Kangaslampi ${ }^{1}$, Henna Asikainen ${ }^{2}$ and Viivi Virtanen ${ }^{3}$ \\ ${ }^{1}$ Unit of Computing Sciences, Tampere University, Finland \\ ${ }^{2}$ HYPE Centre for University Teaching and Learning, University of Helsinki, Finland \\ ${ }^{3}$ HAMK Edu Research Unit, Häme University of Applied Sciences, Finland
}

\begin{abstract}
This study aims at better understanding of the use of self-assessment to support high-achieving students in first-year university mathematics. The students, who had not previously self-assessed their skills and knowledge in mathematics, were given two self-assessment exercises during a calculus course: they assessed their prior knowledge and learning goals in the beginning of the course and the quality of their learning outcomes in the end. Their approaches to learning and perceptions of selfassessment were studied with questionnaires in the beginning and at the end of the course. The students felt that they were able to assess their performance and that self-assessment exercises helped them to learn. Their self-ratings agreed well with the teacher's grading. Self-assessment was implemented to support novice students to adopt a deep approach to learning, and the results showing a statistically significant decrease in unreflective approach give an encouraging signal.
\end{abstract}

ARTICLE DETAILS

LUMAT General Issue Vol 10 No 1 (2022), 1-22

Received 21 May 2021

Accepted 7 December 2021

Published 20 January 2022

Pages: 22

References: 56

Correspondence:

riikka.kangaslampi@tuni.fi

https://doi.org/10.31129/ LUMAT.10.1.1604

Keywords: Mathematics, self-assessment, approaches to learning, grading

\section{Introduction}

Developing the ability to judge the quality of one's own work is one of the core purposes of university studies (Boud et al., 2018). In this context, self-assessment has been regarded as a valuable assessment process that allows students to learn to understand the expectations, criteria and standards used in assessment, to regulate their own learning and to acquire skills for lifelong learning (Boud et al., 2018; Crisp, 2012; Falchikov \& Boud, 1989; Kearney et al., 2016; Panadero et al., 2016). The use of self-assessment has been shown to improve student motivation and engagement (Andrade \& Du, 2007; Ćukušić et al., 2014; Mok et al., 2006; Nikou \& Economides, 2016) as well as self-efficacy (Kissling \& O’Donnell, 2015) and academic performance (Ibabe \& Jauregizar, 2010). Results indicate that the ability to self-assess is intermingled with the ability to self-regulate one's own learning (Panadero et al., 2016) and with lifelong learning skills (Boud, 2000; Crisp, 2012; Kearney et al., 2016), as well as it has a linkage with the approaches to learning the students adopt (Nieminen et al., 2021; Öhrstedt \& Lindfors, 2019). In this study, we take the 
framework of approaches to learning (Asikainen \& Gijbels, 2017; Entwistle, 2009) to explore if the self-assessment activities implemented into course can nourish students' way of studying, namely, to enhance novice mathematic students to adopt deep approach to learning in early stages in their university studies.

Though the importance of the ability to assess own work is viewed evident, university students still scarcely get self-assessment experiences at courses, and further, the students' ability to self-assess the quality of their own work does not systematically improve through education (Boud et al., 2018; Halinen et al., 2014; Postareff et al., 2012). In their paper, Öhrstedt and Lindfors (2019) found that firstsemester students who are new to their discipline have difficulties in estimating their grades. Their study also indicated that low levels of surface approach were linked to better self-assessment skills.

In mathematics, a few pioneers have scientifically studied self-assessment on university level courses (see e.g., Nieminen et al., 2021; Tuohilampi et al., 2018; Warwick \& Howard, 2015), but self-assessment is far from being common practice. Teachers' fear that the students cannot rate accurately and objectively if compared to the ratings done by teachers has been commonly perceived one of the main reasons for resistance (Falchikov \& Boud, 1989), and thus, accuracy has been a question repeatedly examined (González-Betancor et al., 2019). As far as we know there are no results showing that university mathematics teachers' conceptions on assessment would be different. Further, the results from secondary education do not indicate any disciplinary differences when comparing teachers' conceptions on assessment and their assessment practices (Fernández-Ruiz \& Panadero, 2020). However, Brown, Gebri, and Michaelides (2019) concluded that teachers' conceptions of assessment are rather influenced by culture, context, and local factors. Also, mathematics as a conceptual science differs significantly from many other disciplines and therefore results of assessment studies do differ in some respects. For example, mathematics students have been reported to prefer to be assessed by summative assessment methods that are good at discriminating academic ability, which is not in line with the university students' attitudes in general (Iannone \& Simpson, 2015). The results from engineering also show that some students' attitudes toward self-assessment are negative (Willey \& Gardner, 2010). However, if self-assessment is used formatively, as suggested, e.g., by Andrade \& Valtcheva (2009), the focus is not on rating itself, but in obtaining valuable skills through an increased number of self-assessment experiences. Then, the accuracy of one data point of assessment is no longer 
crucial. With more practice the students can improve their ability to assess themselves and to understand the standards and their own competences in relation to those standards.

In this paper, we draw attention to self-assessment practices in university firstyear mathematics by examining an implementation of student self-assessment processes into a class of high achievers. By high achievers here we mean students who have passed the entrance examination to a competitive study programme and who usually get the highest grades showing very good to excellent ability in their university exams. During the self-assessment processes in the course, the students evaluated twice the quality of their learning outcomes according to given criteria. The intended learning outcomes were made transparent through rubric that included both content knowledge and domain-specific generic skills, such as writing mathematics. The emphasis of self-assessment was more in building the metacognition of the learners (Mok et al., 2006) by enhancing awareness of own learning through the selfassessment activities than in developing students' skills to assess quality of one's own work. Approaches to learning give a conceptual frame to explore students' awareness of their own learning as it includes the aspects of unreflective or reflective studying (Lindblom-Ylänne et al., 2019). Hence, the students' perceptions on the benefits of the self-assessment exercises were collected and analyzed as well as the changes in their approaches to learning mathematics. In addition, the students' self-ratings were compared to teacher-ratings to study the accuracy of their assessments to have discipline-specific results of high achievers' skills to assess their own learning outcomes.

\section{Theoretical frame}

\subsection{Self-assessment}

Self-assessment can be defined as a process in which the student evaluates their own achievements and judge their own performance (Falchikov \& Boud, 1989). According to Panadero et al. (2016), "self-assessment is the qualitative assessment of the learning process, and its final product, realized on the basis of pre-established criteria". In accordance, the judgements students make are based on information and evidence about their own performance collected from various sources (Yan \& Brown, 2017). In this paper, we refer to self-assessment as a process during which the students evaluate their own progress and performance and give justifications for the 
results of their evaluation according to teacher-given criteria showing intended learning outcomes.

Students' perceptions on assessment influences how they study, and in consequence, the perceptions affect their learning experience (Biggs, 2003; Struyven et al., 2005). In a recent study (Pereira et al., 2017) exploring students' perceptions on assessment the authors found out that learning was associated with assessment as a positive issue, and further, the student involvement in assessment increased student confidence. Recent study on medical education concluded that students had positive attitudes toward self-assessment and the self-assessment activities promoted their learning as well (Capan Melser et al., 2020). However, Pereira et al. (2017) pointed out that students in different countries as well as in different disciplines show dissimilarities concerning what they value in assessment. Based on these findings, we suggest that in order to enhance the mathematics students to adopt a deep approach to learning by implementing self-assessment activities it is valuable to explore their perceptions on self-assessment.

The accuracy is a fundamental learning target when the ability to assess own learning achievements is trained, and accuracy has been explored intensively since the meta-analysis of Falchikov and Boud (1989), while literature shows diverse results in different settings from quite low accuracy (González-Betancor et al., 2019; Kun, 2016) to high accuracy (Boud et al., 2013; Panadero \& Romero, 2014). Focusing on high-achievers, they tend to underestimate their performance whereas low-achievers tend to overestimate their performance (Boud et al., 2013; Falchikov \& Boud, 1989; Kearney et al., 2016). Hosein and Harle (2018) observed that students' accuracy on their self-assessment in mathematics is associated with their prior mathematical attainment and overall mathematics confidence. Based on their data on undergraduate physics they noticed that students with high or low prior mathematical attainment were more accurate in their self-assessment than students with moderate prior attainment. None of these results concern specifically accuracy of high achievers in university mathematics. Hence, exploring the accuracy of high achievers in university mathematics fills the gap in accuracy literature.

Using criteria and standards help the students to understand (Andrade \& Du, 2007; Panadero \& Jonsson, 2013; Panadero \& Romero, 2014), while students need to have multiple opportunities for practicing self-assessment in relation to given criteria, with feedback to help calibrate the judgements (Hosein \& Harle, 2018; Kearney et al., 2016; Yucel et al., 2014). The students can make reasonable judgements if they are 
properly provided with training and background information to the process, and many studies have found high correlations between student- and teacher-ratings (Asikainen et al., 2014; Boud et al., 2013; Falchikov \& Boud, 1989; Kearney et al., 2016; Panadero \& Romero, 2014).

Results (Boud et al., 2013) indicate that students become more effective in criteria-based judgements both within a subject and a range of subjects over time, and their self-assessments tend to converge with the views of their tutors. However, Boud et al. (2013) argued that the improved skill to assess quality of own work is not immediately transferable, because standards and criteria are somewhat domain-specific and understanding of the expected assignment need to be gained whenever confronted with a new subject matter. Hence, we suggest that to understand the expectations, criteria, and disciplinary standards of university level mathematics, and to develop capabilities to make realistic assessments on own learning processes and outcomes, self-assessment processes should be practiced and implemented already in first-year university mathematics. Taken into account what literature on students' perceptions of assessment says about disciplinary specific and cultural variations (Pereira et al., 2017), meanwhile other literature shows discordant results in students' skills to assess the quality of own work (Boud et al., 2015; Kun, 2016), the students' perceptions on self-assessment and the accuracy aspect as well is worth to be explored among high achievers in university mathematics.

\subsection{Approaches to learning}

Students' approaches to learning have been studied for over forty years. Studying psychology students, Marton and Säljö (1976a) distinguished two different ways of processing a given scientific article. In surface processing the students concentrated on memorizing the text as presented, whilst in deep processing the students concentrated on the meaning of the text. Later, these concepts have been replaced by surface and deep approach that refer to both the students' intentions concerning their studying and learning and the learning processes they apply (e.g., Entwistle \& Ramsden, 1983). The students having surface approach to learning study unreflectively and their knowledge is fragmented, and thus it has been recently suggested that unreflective approach characterises their approach better than surface approach (Lindblom-Ylänne et al., 2019).

These two qualitatively different approaches to learning, the deep approach and the unreflective approach, and their consequences and changes in approach have 
been studied extensively since the 1970's (see e.g., Asikainen \& Gijbels, 2017). Already in the same study by Marton and Säljö (1976a) first evidence was found that students with deep approach learn better than students with surface approach, and subsequent studies have supported this finding (Diseth \& Martinsen, 2003; Minbashian et al., 2004; Trigwell \& Prosser, 1991). In a related study Marton and Säljö (1976b) also found that students can change their approach to learning, and this change can be provoked. Teaching methods affect the approaches to learning (e.g., Entwistle, 2009) as well as the teaching-learning environment (Kyndt et al., 2011). Research has also emphasised the role of assessment in influencing students' approaches to learning (Rust et al., 2005). Marton and Säljö (1976a) already suggested that assessment methods which are designed to support deep level learning may result in difficulties for students who apply surface level processing. There is still a research gap in how self-assessment is related to the way students approach their learning. In a study by Nieminen, Asikainen and Rämö (2021) it was suggested that summative self-assessment can provoke a high deep approach to learning and self-efficacy among mathematics students. Their study was made with a person-oriented approach at the end of a mathematics course and did not consider changes during the course. In this paper we explore the changes in unreflective approach and deep approach in the beginning and at the end of the course using the HowULearn questionnaire by Parpala and Lindblom-Ylänne (2012).

\section{Research questions}

This study aims at gaining a better understanding of how high-achieving students in mathematics experience self-assessment that is used for formative purposes and what are the possible benefits of implementing self-assessment processes on course level in first-year university mathematics. In the course context, self-assessment is used to give the students an opportunity to think metacognitively about their learning, to plan their learning and to reflect on it.

The main purpose of this study is to find out the students' perceptions of the use of self-assessment. It has been shown that although students' attitudes towards selfassessment are negative at the beginning, experience of self-assessment can make the attitude more positive (Andrade \& Du, 2007). Thus, we expect that the experiences of self-assessment will be quite positive. In addition, the knowledge about the students' perceptions nourishes our understanding of the processes needed when teacher-led assessment is developed towards involving students as active participants in the 
assessment.

It has been previously reported that positive perceptions of assessment are positively related to deep approach to learning and negative to surface approach to learning (Parpala et al., 2010) and the use of self-assessment may promote deep approaches to learning (Nieminen et al., 2021). Consequently, we also wish to see a positive change in deep approach to learning and a decrease in unreflective learning to ensure that the students' learning benefits from the self-assessment. Furthermore, we will study the accuracy of the students' self-assessment by comparing the grades they give to themselves to the teacher's grading and analysing their open answers in the self-assessment exercises. The motivation to study qualitative accuracy is to examine whether the students took the self-assessment seriously and paid attention to the rubric while reflecting on their learning.

To summarize, we aim to explore the following questions:

1. What kind of perceptions students have on self-assessment?

2. How do students' approaches to learning change during the course?

3. How accurate are the high-achieving students' self-assessments compared to the teacher's grading?

\section{Methods}

\subsection{Context}

The study was an experimental study carried out during spring term 2018 at Aalto University in Finland on the mathematics course Differential and integral calculus 2 for bachelor students in engineering physics and mathematics. The course lasted 6 weeks and was worth 5 credits (European Credit Transfer and Accumulation System, ECTS). The teaching language was Finnish.

The topics of the course were vector functions and curves, partial differentiation with applications, and multiple integration. The learning objectives were written in the form of a table (see Table 1). They were divided into ten categories, and for each category a list of expected skills and knowledge for grades 1, 3 and 5 was given in the table, the scale of grades being o for fail, $1-5$ for pass, with 5 as the highest grade.

Contact teaching consisted of two 2-hour lectures and two 2-hour problem sessions per week, that is, 48 hours altogether. For the problem sessions the students were divided into groups of about 20 students. In the problem sessions the students 
solved a few problems in class and were given a few as homework, which they then handed in. They also had randomized, automatically assessed online problems that they solved independently. One homework problem each week the students uploaded into the course online learning platform for peer-review: they then later peer-assessed the solutions provided by two fellow students and self-assessed their own solution with the help of an example solution and a peer-review guideline provided by the teacher.

Table 1. Extract of the rubric (translated from Finnish)

\begin{tabular}{|c|c|c|c|c|}
\hline & Prerequisites & Grade 1-2 & Grade 3-4 & Grade 5 \\
\hline $\begin{array}{l}\text { Vectors and } \\
\text { curves }\end{array}$ & $\begin{array}{l}\text { I can write a vector } \\
\text { between two points } \\
\text { as a linear } \\
\text { combination of } \\
\text { basis vectors. } \\
\\
\text { I can calculate dot } \\
\text { product and cross } \\
\text { product for plane } \\
\text { vectors, and I } \\
\text { understand their } \\
\text { geometric } \\
\text { meaning. }\end{array}$ & $\begin{array}{l}\text { I recognize } \\
\text { functions that } \\
\text { represents a curve } \\
\text { on the plane or in } \\
\text { the 3-space. } \\
\text { I can calculate the } \\
\text { coordinate } \\
\text { functions of a } \\
\text { curve given in } \\
\text { vector form and } \\
\text { vice versa. } \\
\text { I can calculate the } \\
\text { tangent } \\
\text { vector of a } \\
\text { curve at a given } \\
\text { point by } \\
\text { differentiating the } \\
\text { position vector. }\end{array}$ & $\begin{array}{l}\text { I can analyze the } \\
\text { parametric form } \\
\text { of a curve in } \\
\text { order to explain } \\
\text { how the plot of } \\
\text { the curve looks } \\
\text { like. } \\
\text { I can calculate } \\
\text { the length of a } \\
\text { space curve by } \\
\text { integrating its } \\
\text { tangent vector. }\end{array}$ & $\begin{array}{l}\text { I know how to find a } \\
\text { curve formed by two } \\
\text { surfaces cutting each } \\
\text { other, and I can find } \\
\text { the curve for some } \\
\text { often-appearing } \\
\text { surfaces. } \\
\text { I can explain why } \\
\text { integral of the } \\
\text { tangent vector gives } \\
\text { the length of the } \\
\text { curve, } \\
\text { I can move between } \\
\text { the implicit form and } \\
\text { the parametric } \\
\text { presentation of a } \\
\text { curve. }\end{array}$ \\
\hline
\end{tabular}

The students collected points from solving the problems during the course, each problem was valid for one to three points out of the total of 108 points. They also got one point each time for doing the peer-review, and four points for doing selfassessment exercises; one point for doing the self-assessment in the beginning of the course and three points for the final self-assessment in the end of the course. In the grading of the course the weight of the final exam was 0.4 and the weight of the total sum of the collected points was o.6. 


\subsection{Participants}

The participants of this study were first year students studying in the Bachelor Programme for Science and Technology with engineering physics or mathematics as their major. In general, they can all be considered to be high achievers in mathematics: Admission to this study programme is highly competitive. Highest grade in mathematics or physics in the national matriculation examination is an entrance criterion for the programme. For students entering through the entrance examination, very high points in mathematics and physics are required. In 2019 this programme required the second highest points of all bachelor of science programmes nationally (see 'Diplomi-insinööri- ja arkkitehtikoulutuksen yhteisvalinta: Aikataulut ja tulokset', 2020). The students admitted to the programme are well-motivated and used to succeed in their studies, especially in mathematics and natural sciences. During their university education, they had already studied two courses of mathematics (5 ECTS each) with very good or excellent grades, and this was their third mathematics course at university level. A total of 64 students started the course and 62 passed it during the spring term, of whom 52 gave their consent to participate in this study. The students had the right to cancel their participation at any point, and the participation did not affect their assessment or teaching in any way.

\subsection{Data Collection and Analysis}

The students were given two self-assessment exercises related to the self-assessment rubric (see Table 1). As the first exercise in the beginning of the course, they were asked to familiarize themselves with the assessment rubric and write a short essay about their current knowledge and goals on this course. The second self-assessment exercise was implemented at the end of the course. In that, the students assessed their own learning by giving themselves grades for each of the 10 categories in the assessment rubric, providing also reasoning for each grade. They also gave themselves a grade for the whole course. They were instructed to give the overall grade based on their assessment of the different categories, but it was left to their own discretion how they formed the grade. The grades the students gave for themselves did not affect the grade they got for the course, but they were given three points for doing the selfassessment, and the total sum of the points collected during the course did influence the final grade. The first self-assessment exercise was implemented as an essay 
question in the online learning platform used on the course, and the second combined both numerical answers and short text answers.

The students' perceptions of self-assessment and their approaches to learning were studied with questionnaires instead of e.g., interviews to give all the students the possibility to participate in the research and to avoid any bias that might occur if only some of the students were involved. The students answered a separate questionnaire twice, at the beginning and at the end of the course. Both times the students' approaches to learning comprising deep approach and surface approach were measured with the HowULearn questionnaire (Parpala \& Lindblom-Ylänne, 2012) with 5 -point Likert scale questions ( $1=$ totally disagree, $5=$ totally agree). In the second questionnaire also the students' perceptions of self-assessment were measured with five 7-point Likert items and two open questions ("Describe in your own words how you experienced self-assessment on this course.", "Could the final grade be determined by self-assessment using criteria like in the second selfassessment exercise on this course?"). The questions on the students' perceptions were formulated especially for this experimental study by the authors, but similar ones have been used earlier (e.g., Andrade \& Du, 2007; Ndoye, 2017; Siow, 2015). The Likert-scaled items are presented in Figure 1 together with the results. The questionnaires were carried out with an online survey tool.

The data of the self-assessments and questionnaires as well as the final grades of the students were collected for the study. In total, 52 of the students filled in the questionnaire on approaches to learning in the beginning of the course, and 32 students again at the end of the course, while 28 students answered the open question concerning their experiences on self-assessment. Of these students, 26 could be matched. Furthermore, 52 students' self-assessment exercises were available for research. To study the first research question, the students' perceptions of the selfassessment were analyzed by SPSS software with descriptive statistics of the Likerttype questions as well as inductive qualitative content analysis of the open-ended data (Mayring, 2014). For the second research question, the change in students' approaches to learning was analyzed by SPSS software with Paired sample t-test. The accuracy of the students' self-assessment, which was the topic of the last research question, was studied by comparing the overall grades the students gave to themselves with the final course grades given by the teacher, and with qualitative content analysis of the justifications and reflections that they wrote in the self-assessment exercises. 


\section{Results}

\subsection{Students' perceptions of self-assessment}

Students' perceptions of self-assessment varied in the course. About $78 \%$ of the 32 students that answered the final questionnaire experienced the self-assessment positively (agreed or partly agreed), see Figure 1 . A total of $40 \%$ of the students partly agreed or agreed that the self-assessment helped them to learn and almost $40 \%$ of students agreed or partly agreed that the self-assessment motivated them to learn. About 25 percent of the students, however, agreed or partly agreed that the selfassessment did not benefit them. In addition, half of the students experienced that they could assess their performance in the course.

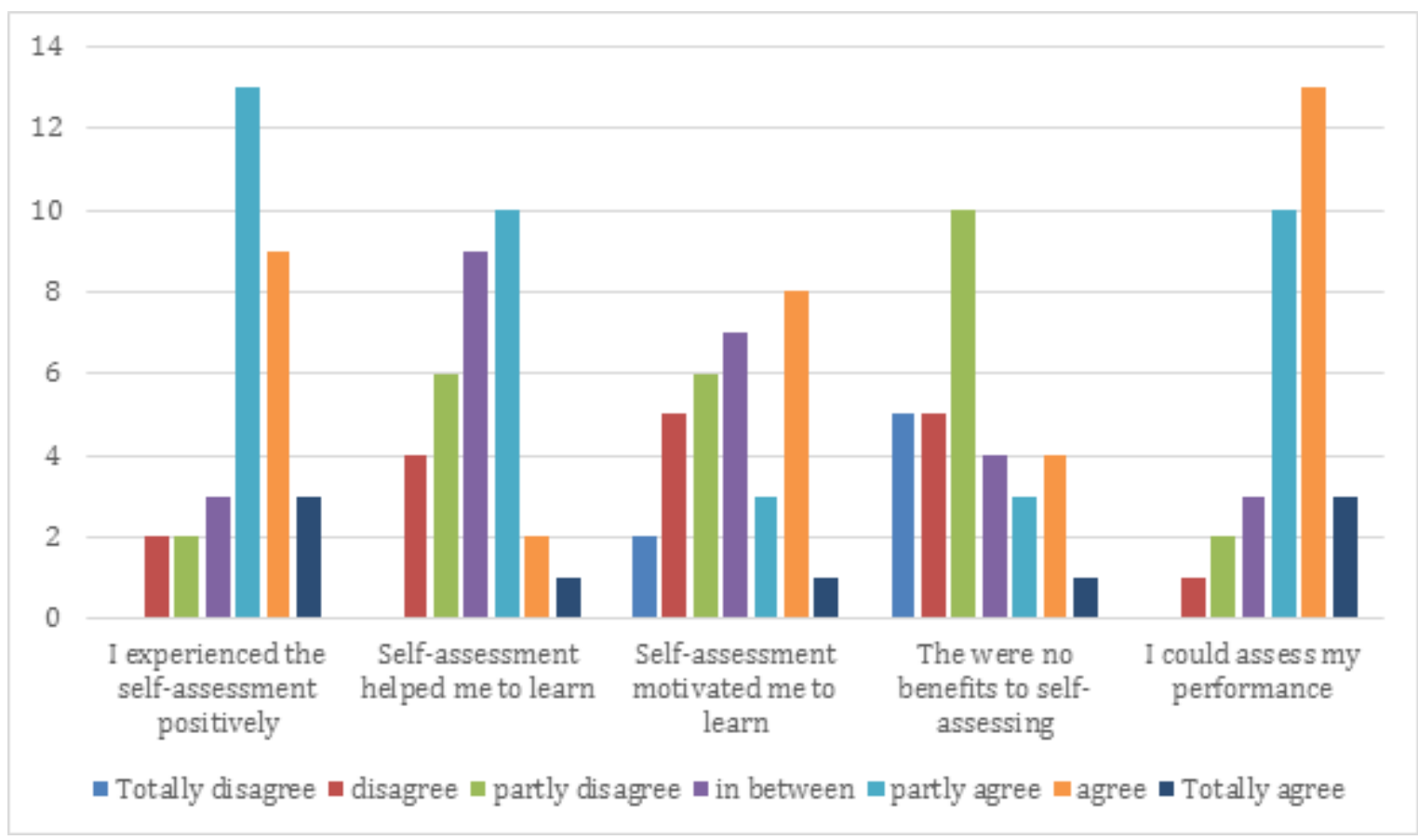

Figure 1 . The students $(\mathrm{N}=32)$ perceptions of self-assessment.

At the end of the course, altogether 28 students described their experiences of self-assessment by answering open questions. In general, the students gave quite economical descriptions containing one to four sentences. In the continuum indicating positive to negative experience, we recognized a few negative experiences $(\mathrm{N}=3)$, but most of the students found the self-assessment either a kind of neutral $(\mathrm{N}=9)$ or a positive experience $(\mathrm{N}=16)$. Further, three qualitatively different categories emerged from the data showing how the students found the self-assessment as a positive learning experience, namely, (1) understanding the performance criteria, (2) 
reflection on current learning, and (3) reflection on future learning. In the following, the difference of the categories as well as the characteristics of each category are given with typical excerpts from the students' responses.

\section{Category 1: Understanding the performance criteria}

In some responses $(\mathrm{N}=4)$, the students emphasized that the self-assessment exercise helped them to understand what the core contents of the course are. Hence, in these responses identifying the contents was in focus, but the learning process forward was not described. Based on the students' descriptions, the rubric itself seemed to help the students to have a coherent understanding of the expectations by listing the themes and sub-contents. Further, the self-assessment exercise with the rubric was experienced useful even if the students did not like doing the exercise, or if they felt that doing the exercise did not have additional value to their learning outcomes, as the following excerpt shows (all excerpts are translated from Finnish by the authors):

" I did not feel that I got much out of it on a concrete level. The good thing was, that it gave a good overview of the topics covered on the course, but I do not believe that it actually made my learning outcomes better at any level." (Student 57)

\section{Category 2: Reflection on the current learning}

In some responses $(\mathrm{N}=10)$, the students described the link between the expectations and their own learning outcomes, and the self-assessment exercise was acknowledged for raising the awareness. Some students $(\mathrm{N}=5)$ emphasized that the self-assessment exercise helped them in considering the gaps in their own knowledge, and hence, to study more if needed. In the end of the course, the self-assessment exercise seemed to work as a tool for repeating the course contents. Thus, in this category the responses emphasized students' own activities in the learning process such as thinking, reflecting, pondering on the level of one's own knowledge as well as on the expectations. Some students $(\mathrm{N}=6)$ seemed to experience the self-assessment positively, as the following excerpt shows:

\footnotetext{
" It was very nice, otherwise I probably would not read the learning objectives so closely. It was nice to see clearly all the things I had to learn and to think how well I had learned. I also reviewed several things while doing the selfassessment." (Student 14)
}

Some other students' descriptions $(\mathrm{N}=3)$ showed that they were aware of the 
usefulness of evaluating one's own skills or knowledge even if they did not like the activity itself:

"Yes, it did make me think whether these topics have really been learned, but I still don't find it particularly pleasant" (Student 23)

Some descriptions $(\mathrm{N}=2)$ showed that there were also students who did not seem to find the kind of teacher-led activity needed but they explained how to self-regulate their learning independently:

"I keep an eye on my learning anyway" (Student 10)

\section{Category 3: Reflection for future learning}

In a few responses $(\mathrm{N}=3)$, the students looked at their competencies specifically through a future perspective. The difference with the Category 2 responses is subtle, but the focus in this category is more on future learning. The students for example describe how the self-assessment exercise helped in clarifying the quality of their own learning and in understanding what to study after the course, as the following excerpt shows:

"At least I found out what topics still need more understanding and what topics would be good to go back to, for example, after the Linear Algebra course." (Student 43)

\subsection{Changes in approaches to learning}

Quantitative analysis on the data collected with the questionnaires showed that there was a statistically significant decrease in students' unreflective approach to learning during the course. The deep approach to learning increased but the change was not significant. Deep approach and unreflective approach correlated negatively with each other (-0.31), but not statistically significantly. The mean values ( $\mathrm{m} 1$ and $\mathrm{m} 2$ ) with standard deviations for unreflective and deep approach in the beginning and in the end of the course, measured with the HowULearn questionnaire (Parpala \& Lindblom-Ylänne, 2012), are presented in Table 2 together with the t-values, p-values and effect size of the Paired sample t-tests. 
Table 2. Changes in approaches to learning during the course.

\begin{tabular}{|l|l|l|l|l|l|l|l|}
\hline & $\mathrm{m} 1$ & $\mathrm{~s}$ & $\mathrm{~m} 2$ & $\mathrm{~s}$ & $\mathrm{t}$ & $\mathrm{p}$ & Cohen's D \\
\hline Unreflective approach & 2.68 & 0.63 & 2.10 & 0.63 & 4.18 & $<0.001$ & 0.816 \\
\hline Deep approach & 3.95 & 0.65 & 4.06 & 0.78 & -1.04 & 0.31 & 0.205 \\
\hline
\end{tabular}

\subsection{Accuracy of the self-assessment}

The data collected from the second self-assessment exercise $\left(\mathrm{N}=5^{2}\right)$ showed that the students were able to grade themselves quite accurately compared to the teacher grading: The average of the total grades given by the students to themselves in the self-assessment was 4.44, when the average of the course grades based on the exam and the collected exercise points for these students was 4.40. Of the 52 students, 28 received in the end the same grade for the course as they assigned to themselves in the self-assessment exercise. Of the 52 students, 12 students received one grade higher, 10 students one grade lower and 2 students two grades lower. The average grades for the five mathematical content topics in the rubric varied between 4.3 and 4.6. Since the exam problems were deliberately chosen in such a way that they combined knowledge from several topics, comparing the exam points with the selfgradings topic by topic was not possible.

Qualitative content analysis of the answers to the self-assessment exercises showed that the students took the self-assessment exercises seriously. In the first selfassessment exercise a great majority of the students (47 out of 52 answers) wrote that they fulfil the prerequisites of the course, only four students commenting that they lack some assumed prior knowledge or skills. Many students realized that there is a lot to learn before the end of the course, exactly half of them commenting that the rubric contains new concepts that they are not yet familiar with. Qualitative content analysis of the second self-assessment exercise $\left(\mathrm{N}=5^{2}\right)$ also showed that, in general, the students put effort in doing the self-assessment exercise. Reflection on own understanding on different topics by self-grading and providing reasoning for own grades had been carried out conscientiously. The reflections showed that in the end of the course the students realized how much and what they have learnt, and they were also able to name the parts that remained unclear, as the following excerpts show. 
"I am able to solve extremal value problems using critical points and the Lagrange method, and I can classify them using the Hessian matrix, but it remains somewhat unclear to me why the Hessian matrix works for this purpose. I understand that it is based on Taylor polynomials and, for example, I can write a secondary Taylor polynomial with the help of the Hessian matrix as an inner product, but I cannot explain why it works." (Student 8)

"I understand and can do most of the things taught on the course, but in the absence of routine to do the calculations, I still need written resources and mathematical programs to support me. I understand that when getting more routine, working on the topics gets more "natural", but I am not there yet. That is why I would not give myself a higher grade than 3, even though I have mostly understood the topics." (Student 45)

\section{Discussion}

Our study focuses on high achievers in university mathematics, and the purpose of this study was to explore students' perceptions of self-assessment, changes in students' approaches to learning and accuracy of self-assessment. Regarding our first research question concerning the students' perceptions of self-assessment, we were especially interested in exploring how the high achievers in mathematics perceive the self-assessment, as this kind of assessment method is quite rarely used in practice in the educational context, while the assessment literature (Boud et al., 2018) encourages it. Our results showed a tendency that mostly the students perceive assessing the quality of one's own work positively. Hence, the students found selfassessment exercises useful and improving their motivation to study. This is in line with previous research which suggests that self-assessment can improve intrinsic motivation (e.g., McMillan \& Hearn, 2008) and that mathematics students mainly experience self-assessment positively (Nieminen \& Tuohilampi, 2020).

Having a deeper insight into students' perceptions on the self-assessment and how they actually experienced it during the course resulted in three categories showing how the self-assessment process was acknowledged to deepen understanding either on the content or on the learning process by raising the awareness. The three categories that resulted from our research, (1) the performance criteria, (2) to reflect on own current learning, (3) to reflect on future learning, share many similarities with the three elements that according to Yan and Brown (2017) are commonly undertaken actions in the self-assessment process: (1) determining the performance criteria, (2) self-directed feedback seeking and (3) self-reflection. The third of the categories observed had the fewest comments with only a couple of the students pondering the quality of their learning in the future, but this might be quite natural for first year 
students with only a limited experience on university studies, while they were not specifically asked to focus on future learning.

Regarding students' perceptions, there was high variation in how the students valued doing the self-assessment exercises, while some, although a minor part of the students, did not experience the self-assessment to be meaningful. In that respect, our results are parallel with previous studies (Asikainen et al., 2014; Willey \& Gardner, 2010) showing that some students feel uncomfortable being involved in assessing their peers' work or their own work. In addition, in university mathematics also it has been found that students may experience self-assessment as new and even weird as opposed to traditional teacher-led exam culture, and students can experience for example helplessness when conducting self-assessment (Nieminen \& Tuohilampi, 2020). In line with Willey and Gardner (2010) we argue that the fact that students feel uncomfortable is the very reason why such tasks as self-assessment should be a regular part of learning activities. Based on our findings we suggest that there need to be frequent possibilities during the university education for students to practice selfassessing the quality of their own work to construct a shared understanding of the quality standards adopted by the discipline, as well as to increase some students' ability to make assessments.

In this study, self-assessment was implemented in the course to support novice university students to adopt a deep approach to learning. In accordance with our second research question, our most striking finding was that the unreflective approach to learning decreased during the course. To our knowledge, no other studies have explored the change in approaches to learning related to self-assessment, but especially self-assessment has been found to be related to deep approach to learning. A negative association between surface approach and self-assessment has been found (Öhrstedt \& Lindfors, 2019). In addition, Nieminen et al., (2021) found that students who were representing a very high deep approach were more represented in a summative self-assessment group than students in the formative self-assessment group. That is to say, if the students were given the possibility to grade themselves, their deep approach was higher. In our study, summative self-assessment was not used but an increase in surface approach was found. This would suggest that the learning environment in the course increased understanding and reflection among students as surface approach to learning can be seen as unreflective studying (Lindblom-Ylänne et al., 2019). One reason for the lack of change in deep approach could be that it had quite a high value already in the beginning of the course, so there 
was perhaps not so much room for improvement. We view it as a promising signal in that letting the students to be involved in assessment and by sharing understanding on quality standards has a positive effect on the students' approaches to learning.

Concerning our third question, our results indicate that these high-achieving students take the self-assessment seriously and put effort into it. In our study, the high achievers seemed to be quite accurate in their grading. The results are somewhat contradicting with the previous research indicating that high achieving students tend to underestimate their performance (Boud et al., 2013, 2015) but better in line with the studies showing that the high-achievers tend to be more accurate in their grading than the low-achieving students our (e.g., González-Betancor et al., 2019). Boud et al (2015) showed that convergence with tutor grading is achieved during time with rehearsal, repetition, and feedback. In our study, the self-assessment was used for learning purposes and in accordance, the accuracy can be seen as an intended outcome of a learning process in which the student rehearses assessing his or her performance based on the given standards and criteria. The study of Boud et al (2018) explored if extended opportunities for self-assessment over time can help students develop the capacity to make better judgments about their work and they concluded that the ability to self-assess is partly transformative capability and partly not. Though the students in our study were already quite accurate in their grading, providing them with more opportunities to self-assess their learning during their mathematics studies, together with support and guidance, would most likely also increase the accuracy of their assessments.

Our results also showed that, in general, the students put effort into doing the self-assessment exercises. Hence, they seemed to be able to identify the gaps they had in their knowledge in the beginning of the course, and further, to understand what they were supposed to learn. This gives a deeper view of the accuracy of the assessment. Reflection on own learning achievements in the end of the course seemed to help the students for example to recognize the level of own scholarship with the prevailing gaps in their current knowledge. This result supports our assumptions that self-assessment can help students to recognize the learning goals and criteria of what is supposed to be learned (McMillan \& Hearn, 2008).

\section{Limitations and Further Study}

This study covers only one course that lasted about six weeks, and in such a short time it is often hard to detect any changes. However, positive experiences and a change in 
surface approach to learning still showed that changes can be made in one course. The number of participants was also fairly small, on a large course with hundreds of students the quantitative data would be more reliable. Even so, the data was still fairly representable.

Our study was also an experimental study in one course and only survey data was used. Thus, students' experiences were the focus of our study. We used validated measures in our questionnaires but also self-made questions which were similar to those used in earlier studies. However, using validated questionnaires could have also been used to improve the validity and reliability of our study. Furthermore, there was no control group: all students on the course participated in the new self-assessment exercises. This is often the case in teaching development projects, if it is expected that a change in teaching should benefit the students. Nevertheless, without a control group it is not certain that the reported changes in the students' approaches to learning were caused by the integrated self-assessment exercises. Since the students only had two self-assessment exercises implemented, together with a weekly selfassessment of one homework problem they handed in, it is quite possible that also other aspects of the course had an effect in the observed change in the unreflective approach.

The use of self-assessment in university mathematics is a topic that is under active research. Even if self-grading likely will not be the norm in university mathematics in the future either, the elements of self-assessment will become more common and therefore the benefits self-assessment can offer should be studied on all levels and contexts. First year students differ a lot from post-graduate students, major students from students taking a few mandatory courses in mathematics etc. Thus, the same kind of self-assessment procedures might not be the best to support learning in all situations, and we need experiences and analysis of different set-ups to be able to support the students in the best possible way.

\section{Acknowledgements}

The authors would like to thank Johanna Rämö for all the discussions and comments on the manuscript. Also, the authors gratefully thank the anonymous referee for their valuable input on improving the quality of the article. 


\section{References}

Andrade, H., \& Du, Y. (2007). Student responses to criteria-referenced self-assessment. Assessment \& Evaluation in Higher Education, 32(2), 159-181.

https://doi.org/10.1080/02602930600801928

Andrade, H., \& Valtcheva, A. (2009). Promoting Learning and Achievement Through SelfAssessment. Theory Into Practice, 48(1), 12-19.

https://doi.org/10.1080/00405840802577544

Asikainen, H., \& Gijbels, D. (2017). Do Students Develop Towards More Deep Approaches to Learning During Studies? A Systematic Review on the Development of Students' Deep and Surface Approaches to Learning in Higher Education. Educational Psychology Review, 29(2), 205-234. https://doi.org/10.1007/s10648-017-9406-6

Asikainen, H., Virtanen, V., Postareff, L., \& Heino, P. (2014). The validity and students' experiences of peer assessment in a large introductory class of gene technology. Studies in Educational Evaluation, 43, 197-205. https://doi.org/10.1016/j.stueduc.2014.07.002

Biggs, J. B. (2003). Teaching for quality learning at university: What the student does (2nd ed). Society for Research into Higher Education : Open University Press.

Boud, D. (2000). Sustainable Assessment: Rethinking assessment for the learning society. Studies in Continuing Education, 22(2), 151-167.

Boud, D., Dawson, P., Bearman, M., Bennett, S., Joughin, G., \& Molloy, E. (2018). Reframing assessment research: Through a practice perspective. Studies in Higher Education, 43(7), 1107-1118. https://doi.org/10.1080/03075079.2016.1202913

Boud, D., Lawson, R., \& Thompson, D. G. (2013). Does student engagement in self-assessment calibrate their judgement over time? Assessment \& Evaluation in Higher Education, 38(8), 941-956. https://doi.org/10.1080/02602938.2013.769198

Boud, D., Lawson, R., \& Thompson, D. G. (2015). The calibration of student judgement through self-assessment: Disruptive effects of assessment patterns. Higher Education Research \& Development, 34(1), 45-59. https://doi.org/10.1080/07294360.2014.934328

Brown, G. T. L., Gebril, A., \& Michaelides, M. P. (2019). Teachers' Conceptions of Assessment: A Global Phenomenon or a Global Localism. Frontiers in Education, 4, 16.

https://doi.org/10.3389/feduc.2019.00016

Capan Melser, M., Lettner, S., Bäwert, A., Puttinger, C., \& Holzinger, A. (2020). Pursue today and assess tomorrow-How students' subjective perceptions influence their preference for selfand peer assessments. BMC Medical Education, 2O(1), 479. https://doi.org/10.1186/s12909020-02383-Z

Crisp, G. T. (2012). Integrative assessment: Reframing assessment practice for current and future learning. Assessment \& Evaluation in Higher Education, 37(1), 33-43. https://doi.org/10.1080/02602938.2010.494234

Ćukušić, M., Garača, Ž., \& Jadrić, M. (2014). Online self-assessment and students' success in higher education institutions. Computers \& Education, 72, 100-109.

https://doi.org/10.1016/j.compedu.2013.10.018

Diplomi-insinööri- ja arkkitehtikoulutuksen yhteisvalinta: Aikataulut ja tulokset. (2020). DIA. https://dia.fi/lisatietojahakemisesta/aikataulut-ja-tulokset/

Diseth, A., \& Martinsen, Ø. (2003). Approaches to Learning, Cognitive Style, and Motives as Predictors of Academic Achievement. Educational Psychology, 23(2), 195-207. https://doi.org/10.1080/01443410303225

Entwistle, N. J. (2009). Teaching for understanding at university: Deep approaches and distinctive ways of thinking. Palgrave Macmillan. 
Entwistle, N. J., \& Ramsden, P. (1983). Understanding student learning. Croom Helm [u.a.].

Falchikov, N., \& Boud, D. (1989). Student Self-Assessment in Higher Education: A Meta-Analysis. Review of Educational Research, 59(4), 395-430.

https://doi.org/10.3102/00346543059004395

Fernández-Ruiz, J., \& Panadero, E. (2020). Comparison between conceptions and assessment practices among secondary education teachers: More differences than similarities (Comparación entre concepciones y prácticas de evaluación en profesores de Educación Secundaria: más diferencias que semejanzas). Journal for the Study of Education and Development, 43(2), 309-346. https://doi.org/10.1080/02103702.2020.1722414

González-Betancor, S. M., Bolívar-Cruz, A., \& Verano-Tacoronte, D. (2019). Self-assessment accuracy in higher education: The influence of gender and performance of university students. Active Learning in Higher Education, 2O(2), 101-114.

https://doi.org/10.1177/1469787417735604

Halinen, K., Ruohoniemi, M., Katajavuori, N., \& Virtanen, V. (2014). Life science teachers' discourse on assessment: A valuable insight into the variable conceptions of assessment in higher education. Journal of Biological Education, 48(1), 16-22. https://doi.org/10.1080/00219266.2013.799082

Hosein, A., \& Harle, J. (2018). The relationship between students' prior mathematical attainment, knowledge and confidence on their self-assessment accuracy. Studies in Educational Evaluation, 56, 32-41. https://doi.org/10.1016/j.stueduc.2017.10.008

Iannone, P., \& Simpson, A. (2015). Students' preferences in undergraduate mathematics assessment. Studies in Higher Education, 40(6), 1046-1067.

https://doi.org/10.1080/03075079.2013.858683

Ibabe, I., \& Jauregizar, J. (2010). Online self-assessment with feedback and metacognitive knowledge. Higher Education, 59(2), 243-258. https://doi.org/10.1007/s10734-009-9245-6

Kearney, S., Perkins, T., \& Kennedy-Clark, S. (2016). Using self- and peer-assessments for summative purposes: Analysing the relative validity of the AASL (Authentic Assessment for Sustainable Learning) model. Assessment \& Evaluation in Higher Education, 41(6), 840853. https://doi.org/10.1080/02602938.2015.1039484

Kissling, E. M., \& O’Donnell, M. E. (2015). Increasing language awareness and self-efficacy of FL students using self-assessment and the ACTFL proficiency guidelines. Language Awareness, 24(4), 283-302. https://doi.org/10.1080/09658416.2015.1099659

Kun, A. I. (2016). A comparison of self versus tutor assessment among Hungarian undergraduate business students. Assessment \& Evaluation in Higher Education, 41(3), 350-367. https://doi.org/10.1080/02602938.2015.1011602

Kyndt, E., Dochy, F., Struyven, K., \& Cascallar, E. (2011). The direct and indirect effect of motivation for learning on students' approaches to learning through the perceptions of workload and task complexity. Higher Education Research \& Development, 3O(2), 135-150. https://doi.org/10.1080/07294360.2010.501329

Lindblom-Ylänne, S., Parpala, A., \& Postareff, L. (2019). What constitutes the surface approach to learning in the light of new empirical evidence? Studies in Higher Education, 44(12), 21832195. https://doi.org/10.1080/03075079.2018.1482267

Marton, F., \& Säljö, R. (1976a). On qualitative differences in learning I: Outcome and process. British Journal of Educational Psychology, 46(1), 4-11. https://doi.org/10.1111/j.20448279.1976.tb02980.x

Marton, F., \& Säljö, R. (1976b). On qualitative differences in learning II: Outcome as a function of the learner's conception of the task. British Journal of Educational Psychology, 46(2), 115127. https://doi.org/10.1111/j.2044-8279.1976.tb02304.x 
Mayring, P. (2014). Qualitative content analysis: Theoretical foundation, basic procedures and software solution.

McMillan, J. H., \& Hearn, J. (2008). Student Self-Assessment: The Key to Stronger Student Motivation and Higher Achievement. Educational Horizons, 87(1), 40-49.

Minbashian, A., Huon, G. F., \& Bird, K. D. (2004). Approaches to studying and academic performance in short-essay exams. Higher Education, 47(2), 161-176.

https://doi.org/10.1023/B:HIGH.0000016443.43594.d1

Mok, M. M. C., Lung, C. L., Cheng, D. P. W., Cheung, R. H. P., \& Ng, M. L. (2006). Self-assessment in higher education: Experience in using a metacognitive approach in five case studies. Assessment \& Evaluation in Higher Education, 31(4), 415-433. https://doi.org/10.1080/02602930600679100

Ndoye, A. (2017). Peer/self-assessment and student learning. International Journal of Teaching and Learning in Higher Education, 29(2), 255-269.

Nieminen, J. H., Asikainen, H., \& Rämö, J. (2021). Promoting deep approach to learning and selfefficacy by changing the purpose of self-assessment: A comparison of summative and formative models. Studies in Higher Education, 46(7), 1296-1311.

https://doi.org/10.1080/03075079.2019.1688282

Nieminen, J. H., \& Tuohilampi, L. (2020). 'Finally studying for myself' - examining student agency in summative and formative self-assessment models. Assessment \& Evaluation in Higher Education, 45(7), 1031-1045. https://doi.org/10.1080/02602938.2020.1720595

Nikou, S. A., \& Economides, A. A. (2016). The impact of paper-based, computer-based and mobilebased self-assessment on students' science motivation and achievement. Computers in Human Behavior, 55, 1241-1248. https://doi.org/10.1016/j.chb.2015.09.025

Öhrstedt, M., \& Lindfors, P. (2019). First-semester students' capacity to predict academic achievement as related to approaches to learning. Journal of Further and Higher Education, 43(10), 1420-1432. https://doi.org/10.1080/0309877X.2018.1490950

Panadero, E., Brown, G. T. L., \& Strijbos, J.-W. (2016). The Future of Student Self-Assessment: A Review of Known Unknowns and Potential Directions. Educational Psychology Review, 28(4), 803-830. https://doi.org/10.1007/s10648-015-9350-2

Panadero, E., \& Jonsson, A. (2013). The use of scoring rubrics for formative assessment purposes revisited: A review. Educational Research Review, 9, 129-144. https://doi.org/10.1016/j.edurev.2013.01.002

Panadero, E., \& Romero, M. (2014). To rubric or not to rubric? The effects of self-assessment on self-regulation, performance and self-efficacy. Assessment in Education: Principles, Policy \& Practice, 21(2), 133-148. https://doi.org/10.1080/0969594X.2013.877872

Parpala, A., \& Lindblom-Ylänne, S. (2012). Using a research instrument for developing quality at the university. Quality in Higher Education, 18(3), 313-328.

https://doi.org/10.1080/13538322.2012.733493

Parpala, Anna., Lindblom-Ylänne, Sari., Komulainen, Erkki., Litmanen, Topi., \& Hirsto, Laura. (2010). Students' approaches to learning and their experiences of the teaching-learning environment in different disciplines. British Journal of Educational Psychology, 8o(2), 269282. https://doi.org/10.1348/000709909X476946

Pereira, D., Niklasson, L., \& Flores, M. A. (2017). Students' perceptions of assessment: A comparative analysis between Portugal and Sweden. Higher Education, 73(1), 153-173. https://doi.org/10.1007/s10734-016-0005-0

Postareff, L., Virtanen, V., Katajavuori, N., \& Lindblom-Ylänne, S. (2012). Academics' conceptions of assessment and their assessment practices. Studies in Educational Evaluation, 38(3-4), 84-92. https://doi.org/10.1016/j.stueduc.2012.06.003 
Rust, C., O’Donovan, B., \& Price, M. (2005). A social constructivist assessment process model: How the research literature shows us this could be best practice. Assessment \& Evaluation in Higher Education, 3O(3), 231-240. https://doi.org/10.1080/02602930500063819

Siow, L.-F. (2015). Students' perceptions on self- and peer-assessment in enhancing learning experience. Malaysian Online Journal of Educational Sciences, 3(2), 21-35.

Struyven, K., Dochy, F., \& Janssens, S. (2005). Students' perceptions about evaluation and assessment in higher education: A review1. Assessment \& Evaluation in Higher Education, 30(4), 325-341. https://doi.org/10.1080/02602930500099102

Trigwell, K., \& Prosser, M. (1991). Relating approaches to study and quality of learning outcomes at the course level. British Journal of Educational Psychology, 61(3), 265-275. https://doi.org/10.1111/j.2044-8279.1991.tboo984.x

Tuohilampi, L., Nieminen, J. H., Häsä, J., \& Rämö, J. (2018). The interplay of informative assessment criteria and continuous feedback with mathematics students' learning orientations. In Proceedings of the 42nd Conference of the International Group for the Psychology of Mathematics Education. PME International Group for the Psychology of Mathematics Education.

Warwick, J., \& Howard, A. (2015). Student Self-Assessment of Mathematical Skills: A Pilot Study of Accounting Student. E-Journal of Business Education and Scholarship of Teaching, 9, 112.

Willey, K., \& Gardner, A. (2010). Investigating the capacity of self and peer assessment activities to engage students and promote learning. European Journal of Engineering Education, 35(4), 429-443. https://doi.org/10.1080/03043797.2010.490577

Yan, Z., \& Brown, G. T. L. (2017). A cyclical self-assessment process: Towards a model of how students engage in self-assessment. Assessment \& Evaluation in Higher Education, 42(8), 1247-1262. https://doi.org/10.1080/02602938.2016.1260091

Yucel, R., Bird, F. L., Young, J., \& Blanksby, T. (2014). The road to self-assessment: Exemplar marking before peer review develops first-year students' capacity to judge the quality of a scientific report. Assessment \& Evaluation in Higher Education, 39(8), 971-986.

https://doi.org/10.1080/02602938.2014.880400 